\title{
Precision policies and Local Content targets in resource-rich developing countries: the case of the oil and gas sector in Mozambique
}

\author{
Marika Arena ${ }^{\text {a }}$, Giovanni Azzone ${ }^{\mathrm{a}}$, Laura Dell'Agostino ${ }^{\mathrm{a} *}$, Francesco Scotti ${ }^{\mathrm{a}}$ \\ ${ }^{a}$ Department of Management, Economics and Industrial Engineering, Politecnico di Milano (Italy) \\ *laura.dellagostino@polimi.it
}

\begin{abstract}
This paper aims to understand whether and to what extent firm-level data can "precisely" support the definition of the Local Content (LC) targets for international oil and gas companies in resource-rich developing countries. The paper addresses this topic with reference to a specific, publicly available dataset developed by the World Bank Enterprises Survey (ES) Unit and uses the case of Mozambique to demonstrate the informative potential of firm-level data for policy-making. Specifically, we compare the LC estimates obtained using firm-level data with those obtained using sector-level data (input-output tables). Based on this comparison, we demonstrate that firm-level data provide a more accurate representation of the capability of the domestic supply chain to provide inputs to the oil and gas industry, while input-output tables lead to a significant overestimation of LC. Overall, our findings suggest that firm-level data can provide a more precise basis for supporting the design of LC policies and the Enterprise Survey for Mozambique could represent a reference model for data collection to be extended to other resource-rich developing countries to support target definition.
\end{abstract}

Keywords - Precision policies; Firm-level data; Local content; Oil and gas; Mozambique.

\section{Introduction}

In recent years, the growing availability of more detailed and timely data has been a game changer in many sectors (Maciejewski, 2017), leading to the adoption of so-called "precision policies". Compared to a "standard" public policy, a precision policy defines a set of interventions taking into account the specific characteristics and expectations of homogeneous groups of users (or even a single user, if data are available), enabling a more efficient and effective usage of public resources (Azzone, 2018).

In the energy sector, precision policies have progressed very differently between developed countries and resourcerich developing countries.
In the former, the diffusion of smart grids, smart meters, sensors, digital devices and the "Internet of Things" made large amounts of data on energy demand easily available, supporting the implementation of precision policies aimed at optimizing energy consumption and at reducing the sectoral environmental impact (Grolinger et al., 2016).

In the latter, instead, the issues connected to the exploitation of energy resources have a key role and policy makers tend to focus on policies at the intersection between energy, industrialization and economic diversification as instruments to support long-term growth (Adewuyi and Oyejide, 2012; Emmanuel, 2016; Ovadia, 2016). Here, the adoption of precision policies is more complex especially because many developing countries do not have reliable and complete datasets and the cost of collecting information is extremely high, leading to the "poor numbers-poor policy" dilemma (Jerven, 2013). Emblematic is the case of African countries, which have a significant place in the global energy value chain, also thanks to recent discoveries in Sub-Saharan Africa (e.g., Ghana, Mozambique, Tanzania), but face huge challenges in the design and implementation of effective policies also due to the lack of good-quality data (Balchin, 2015).

Moving from these considerations, this paper focuses on a key issue for resource-rich developing countries, analysing how available data can be used to determine Local Content (LC) targets for the multinational companies that want to develop oil and gas projects in these countries. The attention around this topic has significantly increased in recent years since LC - generally considered as the contribution of a multinational company to local development through the purchase of local goods and services and the development of skills - can activate longterm and sustainable economic development, leveraging on production links that connect different industrial sectors (NRGI, 2015). To enable this process, Local Content Policies (LCPs) often contain targets expressed in terms of the minimum share of local inputs of goods, services and 
workforce that multinational companies must (or are invited to) satisfy in their projects. Identifying the most appropriate data to support defining LCPs is crucial for the design of effective policies.

Against this background, the purpose of this paper is to show how the dataset developed by the World Bank Enterprises Survey (ES) Unit through a special survey designed for Mozambique can support resource-rich developing countries in "precisely" defining LC targets for international oil and gas companies (IOCs). The paper aims to answer two research questions:

1. Does the World Bank ES dataset for Mozambique enable setting LC targets more accurately than alternative data sources (i.e., conventional national accounts)?

2. Can the World Bank ES special survey for Mozambique represent a model for data collection to support LCPs definition in other resource-rich developing countries without reliable statistical data?

The case of Mozambique demonstrates the informative potential of firm-level datasets for policy design. The country is part of the new resource boom in Africa and the offshore gas discoveries in the Rovuma fields could host the largest investment project in Sub-Saharan Africa, estimated at around USD 100 billion (Roe, 2018) and LCPs are on top of the agenda of Mozambican policy makers. At the same time, Mozambique is emblematic also of the difficulty in accessing data since the country is characterized by low statistical capacity (World Bank: Statistical Capacity Indicator Dashboard).

The rest of the paper is articulated into four sections. Section 2 presents the state of the art on LC targets, highlighting the main limitations of current approaches. Section 3 illustrates the data and describes the methodology adopted to identify the LC target. Section 4 shows the empirical results obtained for the Mozambique case study and compares the targets estimated through firm-level data from ES against those obtained using traditional approaches. Section 5 concludes.

\section{Background}

LCPs are regulations introduced in resource-rich developing countries to leverage natural resources to maximise the potential for the development of local economies (Ovadia, 2015; Nwapi, 2016). Specifically, LCPs aim to activate productive linkages between the extractive sector and the economy as a whole through the use of domestic intermediate goods and services and the recruitment of the local workforce in oil and gas projects (IPIECA, 2011). Therefore, the definition of the shares of local inputs - i.e., the LC targets - that IOCs must (or are invited to) satisfy is a central element in the design of an LCP and an issue subject to lively debate in LCP literature.
Most authors suggest adopting quantitative and mandatory LC targets to encourage IOCs to use locally sourced goods, services and workforce beyond what they would normally do (White, 2017; Roe, 2018; Pereira et al. 2018), arguing that otherwise IOCs generally tend to import a larger share of their inputs and devote limited concern to the activation of domestic development. However, LC targets might generate additional costs for IOCs when domestic firms are less efficient than international suppliers, with consequently lower tax revenues (Hansen et al., 2016; Rui et al., 2018), inefficiencies and misallocation of resources (Hufabuer et al., 2013; Kolstad and Kinyondo, 2017).

To balance these issues, policy makers should set LC targets consistent with the existing local capabilities (Tordo et al., 2013; Aoun and Mathieu, 2015; Ramdoo, 2015), stimulating IOCs to purchase in the country all inputs that can be produced efficiently (Heum et al., 2011; Kazzazi and Nouri, 2012; Adedeji et al., 2016). The availability of data able to assess the actual capacity of local firms is hence a key to setting LC targets (Klueh, 2009; Acheampong et al., 2016; Pereira et al., 2018), avoiding both unambitious LC targets with limited incentive for IOCs to identify local suppliers (Nwapi, 2015), and unattainable LC targets that cannot be satisfied by the domestic business environment, discouraging potential investors (Teka, 2012).

Available datasets for the assessment of local supply capabilities differ according to their unit of analysis.

A first group of datasets provide information at the sector level, usually through the national Input-Output tables (hereinafter IOTs) (Tordo et al., 2013). IOTs provide a schematic representation of all flows of domestic intermediate goods and services among sectors, with a separate indication of the imports (see Timmer et al., 2012 for an introduction to IOTs). In this way, IOTs offer information about the amount and type of intermediate input needed in the production of one unit of output in a given sector provided within a country (Leontief, 1936).

Sector-level datasets are available also in most developing countries. However, the reliability of this approach has been increasingly questioned. For instance, using IOTs from the Global Trade Analysis Project (GTAP) database ${ }^{1}$, Tordo et al. (2013) calculate the LC levels for the oil and gas sector of 48 countries as the ratio of domestic intermediate goods and services to total intermediates, obtaining results of $80 \%$ or more for 25 countries, between $40 \%$ and $79 \%$ for 17 countries, while only 6 countries have a LC level between $20 \%$ and $39 \%$, all figures significantly higher than those actually achievable in practice and reported in real-case studies (Nordås et al., 2003; Tordo and Anouti, 2013). They attribute such discrepancies to the IOTs used for the analysis. Specifically, in many

\footnotetext{
${ }^{1}$ See https://www.gtap.agecon.purdue.edu/databases/v10/index.aspx
} 
developing countries IOTs have a low level of sectoral disaggregation and oil and gas is usually considered within the mining and quarrying sector, together with the extractive activities that use different technologies and inputs, with different potential for LC. Consequently, IOT data on mining and quarrying sector do not provide a precise representation of the needs of oil and gas companies and of the availability of suppliers in the country.

On the contrary, in a few countries, national authorities in charge of the design and implementation of the LCP created project-level datasets. An example of this type of dataset is used by Furtado et al. (2017) for the revision of Brazilian LC targets. The authors exploited the LC shares for each equipment item and service certified by firms accredited by the National Petroleum Agency in order to measure the socio-economic impact of an oil and gas project. Such approach allows the identification of realistic targets, as the information is both country and product/service specific. However, it requires a large set of data concerning past oil and gas projects, which is feasible in well-established extractive countries - as in the case of Brazil presented by Furtado et al. (2017) - but is not realistic in countries that have recently entered the oil and gas industry, including Sub-Saharan regions, and are not equipped with consistent statistical infrastructures.

In these contexts, a possible solution is provided by firmlevel datasets that are becoming increasingly available and whose quality is improving. Concerning developing countries, a relevant dataset is the Word Bank Enterprise Survey (ES) provided by the Enterprises Analysis Unit of the World Bank, which is conducting extensive enterprise surveys to make firm-level data available. The ES represents a rich source of information about firms that operate in non-agricultural, formal private sectors in more than 140 countries. Moreover, in every country some core sectors are selected on a 'case-by-case' logic for a special survey, whose results are included in the ES dataset. Mining and quarrying is the sector selected for Mozambique and the ES for this country includes some specific questions about the share of domestic inputs used for production and allows the identification of a subset of firms that are suppliers of the extractive sector. These ES firm-level data seem to be well suited for supporting the definition of LC targets in the oil and gas sector. As follows, we analyse if and how they can be applied to provide more accurate estimates of LC targets than IOTs.

\section{Data and methodology}

LC targets can be expressed in two different ways.

According to a first, more common definition, LC is the "share of goods and services provided by first tier domestic suppliers against IOCs total supplies" (Tordo et al., 2013; Furtado et al., 2017). We call it Gross LC, as it measures the actual impact of a project on local companies only if all domestic suppliers do not use imported inputs. Usually, such assumption is not verified in practice, hence the Gross LC overestimates the effect of the IOC on local economy. For this reason, some countries consider the quantity of domestic purchases at different levels of the supply chain, offsetting the value of imports of goods and services provided by "further-level" suppliers. For instance, in Mexico, the LCP refers to the value of Mexican goods used by the IOC, including only the proportion of domestic materials "incorporated" into the goods and excluding the value of imported input along different levels of the supply chain (Asali et al., 2015). We define the LC measure obtained by offsetting suppliers' imports as Net LC.

Net LC can be determined at different levels of precision and completeness. On the one hand, we can just focus on the effect of first-tier suppliers, determining Net LC as the difference between Gross LC and import of first tier suppliers. On the other hand, we could take into account the whole supply chain, as in the Mexican case. The latter approach improves the quality of results, but requires a larger set of data, which can hardly be available in energyrich and data-poor countries. Accordingly, we adopt the former approach, measuring NLC as the share of goods and services provided by first-tier domestic suppliers, net of their imports, against IOCs total supplies. However, our results can be easily extended to a more extensive definition of Net LC.

Below, we outline how Gross LC and Net LC can be calculated relying on the IOT and the ES datasets. To this aim, we first describe the two data sources and the data pre-processing activities needed to make the datasets comparable; then, we present in detail the methodology adopted to compute LC targets.

\subsection{Data sources and pre-processing}

Our first data source is the Eora database that provides IOTs for the years 1990-2015 for 190 countries, offering a valuable alternative for countries - such as Mozambique whose national statistical offices do not disclose IOTs (Lenzen et al., 2013). Specifically, for Mozambique the Eora IOT presents a detailed breakdown of 25 sectors at 2digit level of the International Standard Industrial Classification (ISIC) of all economic activities (see Lenzen et al., 2013). We use the average data of the three most recent years (2013-2015) to prevent bias due to yearly fluctuations.

Our second data sources are the two Mozambique ESs compiled by the World Bank in 2018 with reference to the 
previous fiscal year ${ }^{2}$. One is the standard ES that covers 601 firms in formal Mozambican private sectors and comprises manufacturing (ISIC Revision 3.1 - group D), construction (group F), services (groups $\mathrm{G}$ and $\mathrm{H}$ ), and transport, storage, and communications (group I). The other focuses on 49 firms from the extractive sector (mining and quarrying according to ISIC nomenclature) and has been compiled by the World Bank specifically for this country ${ }^{3}$. Data collection for both surveys is based on the same questionnaire and beside standard business it includes some country-specific questions that are wellsuited to estimate the share of LC. First, Mozambican enterprises are required to declare the share of inputs of domestic origin used in production, which represents the share of inputs purchased from domestic suppliers over total inputs and is a good proxy of their Gross LC (Questionnaire variable d12a). Second, local firms have to state if they are suppliers of goods and services to companies in the extractive sector or not (Questionnaire variable $\mathrm{MZd} 2$ ). In addition, for each firm the dataset provides the ISIC code at 4-digit level of the main product traded and its share with respect to total annual sales, allowing us to distinguish oil and gas firms from companies operating in other extractive sub-sectors (i.e., quarrying of stone, sand and clay; extraction of salt).

Table 1 Composition of the sample by sector

\begin{tabular}{|c|c|c|c|}
\hline \multirow[b]{2}{*}{$\begin{array}{l}\text { ISIC code } \\
\text { ( } 2 \text { digit) }\end{array}$} & \multirow[b]{2}{*}{ Sectors } & \multicolumn{2}{|c|}{$\mathrm{N}^{\circ}$ of Firms } \\
\hline & & Full sample & $\begin{array}{c}\text { of which } \\
\text { Extractive } \\
\text { sector } \\
\text { suppliers }\end{array}$ \\
\hline $10,11,12,13,14$ & Mining and Quarrying & 42 & 17 \\
\hline 15,16 & Food and Beverages & 84 & 11 \\
\hline $17,18,19$ & Textiles and Wearing Apparel & 22 & 0 \\
\hline $20,21,22$ & $\begin{array}{l}\text { Wood and Paper } \\
\text { Petroleum, Chemical and }\end{array}$ & 40 & 4 \\
\hline $23,24,25,26$ & $\begin{array}{l}\text { Non-Metallic Mineral } \\
\text { Products }\end{array}$ & 24 & 1 \\
\hline 27,28 & Metal Products & 64 & 7 \\
\hline $29-33$ & Electrical and Machinery & 13 & 5 \\
\hline 34,35 & Transport Equipment & 2 & 2 \\
\hline 36 & Other Manufacturing & 35 & 3 \\
\hline 45 & Construction & 41 & 14 \\
\hline 50 & Maintenance and Repair & 29 & 10 \\
\hline 51 & Wholesale Trade & 23 & 8 \\
\hline 52 & Retail Trade & 104 & 15 \\
\hline 55 & Hotels and Restaurants & 79 & 19 \\
\hline $60-63$ & Transport & 32 & 17 \\
\hline 64 & Post and Telecommunications & 5 & 0 \\
\hline $65-74$ & $\begin{array}{l}\text { Financial Intermediation and } \\
\text { Business Activities }\end{array}$ & 6 & 2 \\
\hline
\end{tabular}

Combining the two ES datasets and excluding only five observations with missing values for the share of inputs of domestic origin, we obtain a sample composed of 645

\footnotetext{
${ }^{2}$ Given the high stability of the main relationships underlining IOTs, the misalignment between the period covered by IOTs (2013-2015) and the year of the ES (2017) can be considered negligible.

${ }^{3}$ See https://www.enterprisesurveys.org/en/methodology
}

companies (over $99 \%$ of the firms in the original dataset), 135 of which are suppliers of the extractive sector (representing about $21 \%$ of our sample).

Finally, we match our ES firm-level data with IOT data to make comparable the results coming from the two alternative data sources. In doing so, we are forced to reduce the level of detail of the ES dataset by assigning to each firm the corresponding IOT sector (defined at the 2digit level of the ISIC classification) based on the 4-digit ISIC code of the main product. In this way, in both datasets data aggregation is at the 2-digit level of ISIC, in line with the Eora IOT sectoral breakdown. The result is an ES firmlevel sample that covers 17 of the 25 IOT sectors (Tab. 1).

\subsection{LC estimation}

\subsubsection{Gross LC}

Gross LC (GLC) measures the share of goods and services provided by first-tier domestic suppliers against IOC total supplies.

Based on IOTs, the GLC of a sector is determined following Tordo et al. (2013) as the ratio between domestic purchases of intermediate goods and services of the sector and total purchases of intermediate goods and services of the sector, which include also imported inputs. Hence, for each sector i, GLC is obtained according to Eq.1:

$$
G L C_{i}(\text { IOTs })=\frac{\text { Purchases of Domestic Intermediate Goods and Services }}{\text { Total Purchases of Intermediate Goods and Services }}
$$

In general, using ES firm-level datasets, we could obtain the same measure by aggregating data from the firms belonging to each sector i, following Eq. 2:

$$
G L C_{i}(E S)=\frac{\sum_{j=1}^{n} \text { Purchases of Domestic Intermediate Goods and Services }}{\sum_{j=1}^{n} \text { Total purchases of Intermediate Goods and Services }}
$$

where $\mathrm{n}$ is the number of firms in sector i. However, we cannot use Eq. 2 as only 284 companies out of 650 provide the absolute value of the cost of domestic intermediates. For a larger number of companies (645), the dataset only contains the share of domestic inputs used in production. In this case, we can provide a different measure of the GLC (Eq. 3):

$$
G L C_{i}(E S)=\frac{\sum_{j=1}^{n} \text { Percentage of Domestic Inputs }}{\text { Number of firms in sector } i}
$$

Eq. 3 introduces a possible bias because it does not take into account firm size and, consequently, the absolute quantity of domestic goods and services. We have analysed this issue and discussed the robustness of our results in an Appendix that, due to space constraints, is available on request.

\subsubsection{Net LC}

As we clarified above, we measure Net LC (NLC) as the share of goods and services provided by first-tier domestic suppliers net of their imports against IOC total supplies. 
NLC has to be estimated with reference to a specific project, since it requires knowing the industries where suppliers operate. Specifically, we perform our exercise starting from a given total GLC of a project and use three groups of data to determine NLC: (1) the project cost structure; (2) the share of domestic purchases of the IOC for each activated sector; and (3) the share of imports of each activated sector.

The project cost structure defines which sectors are activated by the project and their relative weight in terms of incidence over the total cost of the project (qi). In this paper, we refer to a "reference" oil and gas project that is going to be realized in Mozambique, for which public information is available: the Rovuma Liquefied Natural Gas (LNG) Project situated on the Afungi Peninsula in Cabo Delgado Province ${ }^{4}$.

The share of domestic purchases of the IOC for each activated sector (xi) defines how the GLC is distributed among the sectors activated by the project. The linear combination between the incidence over the total cost of the project of each activated sector (qi) and the sectoral shares of domestic purchases of the IOC (xi) should equal the total GLC of the project according to Eq.4:

$$
G L C=\sum_{i=1}^{n} q_{i} x_{i} \quad \text { where } x_{i} \in[0,1], \quad \sum q_{i}=1
$$

where $\mathrm{i}$ represents the sectors activated by the oil and gas project.

To solve Eq. (4), where the unknown variables are the shares of domestic purchases $\mathrm{x}_{\mathrm{i}}$, we introduce an additional hypothesis, assuming that the share of domestic purchases in each sector is proportional to the portion of local production in the corresponding sector on the local market (yi): more specifically, the higher the local production, the larger the share of domestic purchases in the considered sector. To this aim, we first define $y_{i}$ as the incidence of the sectoral domestic production over the sum between sectoral imports and domestic production (Eq. 5):

$$
y_{i}=\frac{\text { out }_{i}}{\text { out }_{i}+\text { im }_{i}}
$$

where out $\mathrm{i}_{\mathrm{i}}$ is the total output of sector $\mathrm{i}$, obtained from IOTs (in line with GLC elaborations we use the average of the period 2013-2015) and $\mathrm{im}_{\mathrm{i}}$ is the value of imports of goods and services at country level that can be associated to a specific sector $i$, obtained from the UN Comtrade dataset (average 2013-2015) ${ }^{5}$. Second, we assume that the

\footnotetext{
4 Detailed information and reports are available on the website https://www.exxonmobil.co.mz/en-MZ/About/Who-we-are/RovumaLNG\#Overview

${ }^{5}$ It is noteworthy that IOTs record for each sector the imported production inputs, regardless of the sector of origin of those inputs. This means that the imports associated to a sector in IOTs encompass imports procured by the underlying sector across different sectors. Consequently, the factor $\mathrm{im}_{\mathrm{i}}$, which represents the quantity of goods and services belonging
}

ratio between the share of domestic purchases of the IOC and the portion of local production is constant across sectors (Eq. 6):

$$
\frac{x_{i}}{y_{i}}=k
$$

Combining Eq. (4) and (6) ${ }^{6}$ we determine $\mathrm{k}$ and consequently all the xi, which represent the GLC generated by the IOC in each activated sector. Finally, we multiply the share of local purchases of the IOC, weighted by the incidence of activated sectors over the total project value (xi qi), by the portion of domestic inputs purchased by each activated sector (GLCi) to offset the quantity of imports of first-tier suppliers (Eq. (7):

$$
N L C=\sum_{i=1}^{N} q_{i} x_{i} G L C_{i}
$$

\section{Results}

This section presents the results of the analysis for both GLC and NLC.

\subsection{Analysis of Gross LC}

Table 2 shows the GLC obtained from IOTs and ES dataset for all sectors. The table compares the results for the Full sample, including all firms interviewed by the World Bank, the "Extractive sectors suppliers" subset, encompassing only companies that provide inputs to the extractive industry and the "Other firms" subset, with all firms not included in the "Extractive sector suppliers" subset. The comparison of the results sheds light on the peculiarities of the extractive industry, and more specifically the oil and gas industry, with respect to other sectors in terms of local purchases and capability of activating local supply chains. First, for each industry sector, the GLC of the Full sample (Eq. 2) reflects the sectoral average value of the sample and proxies from a firm-level perspective the average value of the country obtained by IOT (Eq. 1), making the two results comparable. This comparison seems to confirm that IOTs generally overestimate the GLC share in most sectors. In some cases, it is very evident, as for example in transport and transport equipment and in wholesale and retail trade. In other cases, the two figures are more aligned (e.g., mining and quarrying).

specifically to the single sector $i$ that is imported, cannot be computed through IOTs. For this reason, we rely on international trade data - i.e., UN Comtrade data (https://comtrade.un.org/). More in detail, since trade data record the imported goods and services by product and not by sector, it is necessary to associate each imported input with its own production sector and then sum the value of the inputs produced by the same sector. We perform this step according to the international classifications of trades goods (SITC) and services (EBSOP).

${ }^{6}$ Combining Eqs. (4) and (6) we obtain: $G L C=k \sum_{i=1}^{n} q_{i} y_{i}$ leading to $k=\frac{G L C}{\sum_{i=1}^{n} q_{i} y_{i}}$. Finally, from Eq. (6) we compute: $x_{i}=k * y_{i} \quad \forall i$. 
Table 2 GLC by sector from different sources and sub-sample, \%

\begin{tabular}{|c|c|c|c|c|}
\hline Sectors & $\begin{array}{c}\text { IOTs } \\
\text { Avg. } \\
2013- \\
2015\end{array}$ & $\begin{array}{l}\text { ES Full } \\
\text { sample }\end{array}$ & $\begin{array}{c}\text { ES } \\
\text { Extractive } \\
\text { sector } \\
\text { suppliers }\end{array}$ & $\begin{array}{l}\text { ES Other } \\
\text { firms }\end{array}$ \\
\hline Mining and Quarrying & 78.49 & 78.86 & 63.53 & 89.28 \\
\hline Food and Beverages & 84.52 & 85.92 & 71.82 & 88.04 \\
\hline $\begin{array}{l}\text { Textiles and Wearing } \\
\text { Apparel }\end{array}$ & 72.46 & 72.73 & - & 72.73 \\
\hline $\begin{array}{l}\text { Wood and Paper } \\
\text { Petroleum, Chemical and }\end{array}$ & 71.66 & 85.13 & 47.50 & 89.31 \\
\hline $\begin{array}{l}\text { Non-Metallic Mineral } \\
\text { Products }\end{array}$ & 70.64 & 59.92 & 60.00 & 59.91 \\
\hline Metal Products & 69.25 & 68.50 & 36.86 & 72.39 \\
\hline Electrical and Machinery & 70.58 & 60.31 & 43.00 & 71.13 \\
\hline Transport Equipment & 73.36 & 30.00 & 30.00 & \\
\hline Other Manufacturing & 75.41 & 90.83 & 66.67 & 93.09 \\
\hline Construction & 90.79 & 78.29 & 70.36 & 82.41 \\
\hline Maintenance and Repair & 66.65 & 61.31 & 69.70 & 56.89 \\
\hline Wholesale Trade & 84.14 & 58.26 & 35.63 & 70.33 \\
\hline Retail Trade & 92.03 & 67.86 & 52.93 & 69.69 \\
\hline Hotels and Restaurants & 86.63 & 82.38 & 75.53 & 84.55 \\
\hline Transport & 84.65 & 58.13 & 46.47 & 71.33 \\
\hline $\begin{array}{l}\text { Post and } \\
\text { Telecommunications }\end{array}$ & 88.93 & 77.00 & - & 77.00 \\
\hline $\begin{array}{l}\text { Financial Intermediation } \\
\text { and Business Activities }\end{array}$ & 70.94 & 64.17 & 100.00 & 46.25 \\
\hline
\end{tabular}

Second, focusing on the comparison of the different ES subsets, for the extractive sectors suppliers, GLC is lower than in the Full sample suggesting that extractive firms require a higher share of imported inputs compared with the sectoral average. This result is in line with the literature, which highlights that most of the Mozambican firms are not able to meet the high international standards required for being part of the extractive industry supply chains (AfDB et al. 2016). This outcome is even evident observing GLC shares of the Other firms' sub-sample, which show higher values for all sectors. This pattern suggests that the extractive sector has peculiar characteristics with respect to the other industries in the local value chain, experiencing on average significantly lower levels of local purchases.

Moreover, taking full advantage of the ES database, we analyse the difference that emerges moving to a higher granularity level from IO sectors (ISIC code, 2 digit) to the ISIC code at 4 digits. In this way, we can investigate GLC associated to the different sub-sectors that compose the extractive sector. Focusing on mining and quarrying, Table 3 shows how similar GLC at sectoral level hides a high heterogeneity among sub-sectors, from a maximum value of about $98 \%$ in the extraction of salt to a minimum of $10 \%$ in the extraction of crude petroleum and natural gas. This result corroborates the weaknesses of IOTs that aggregate within the mining and quarrying sector heterogeneous industries, significantly overestimating the percentage of domestic purchases of oil and gas, which is a capital-intensive industry requiring technologically complex inputs that in developing countries can hardly be provided by the local supply chain in large quantities.
Table 3 GLC in the Mining and Quarrying sector by ISIC code

\begin{tabular}{|c|c|c|c|}
\hline $\begin{array}{l}\text { ISIC } \\
\text { code }\end{array}$ & Sectors & IOTs & $\begin{array}{l}\text { ES Full } \\
\text { sample }\end{array}$ \\
\hline & & $\%$ & $\%$ \\
\hline $\mathrm{C}$ & $\begin{array}{l}\text { Mining and Quarrying } \\
\text { of which }\end{array}$ & 78.49 & 78.86 \\
\hline 1010 & Mining and agglomeration of hard coal & & 57.86 \\
\hline 1110 & $\begin{array}{l}\text { Extraction of crude petroleum and } \\
\text { natural gas }\end{array}$ & & 10.00 \\
\hline 1320 & $\begin{array}{l}\text { Mining of non-ferrous metal ores, } \\
\text { except uranium and thorium ores }\end{array}$ & & 82.86 \\
\hline 1410 & Quarrying of stone, sand and clay & & 92.14 \\
\hline 1422 & Extraction of salt & & 97.86 \\
\hline 1429 & Other mining and quarrying n.e.c. & & 66.40 \\
\hline
\end{tabular}

To summarize, GLC estimated from IOTs (i.e., the share of domestic production inputs over total inputs) is around $78.5 \%$ considering the mining and quarrying sector. This percentage falls to $63.5 \%$ moving to GLC from ES extractive sector suppliers and sharply drops to $10 \%$ focusing specifically on the extraction of crude petroleum and natural gas sub-sector in the ES.

The GLC obtained from the ES for the oil and gas subsector is consistent with those obtained from some publicly available data about two ongoing oil and gas projects in Mozambique. For the Rovuma LNG Project, the Standard Bank Group (2019) reports the estimates of the share of domestic input over total investment to be around $9 \%$ in the construction phase and $10 \%$ during the operational phase $^{7}$. Moreover, all these estimates for Mozambique are in line with the preliminary assessment by the World Bank Group (2016) of an LNG project in Tanzania, a country near Mozambique in terms of level of development and oil and gas maturity ${ }^{8}$. In Tanzania, out of a total LNG investment projected to be around USD 17 billion, the potential for GLC is expected to be around $11 \%$ of the total demand for goods and services.

This first result suggests that the usage of sector-level datasets might lead policy makers to set LC targets which are far from the real potential of the domestic market and which do not reflect the capabilities of the local economic and industrial structure. This offers a strong empirical support to the use of firm-level data-such as the Mozambique ES - in the definition of LC targets of the oil and gas industry, especially in countries characterized by a limited availability of reliable statistics.

\footnotetext{
${ }^{7}$ See: https://www.mzlng.total.com/en

${ }^{8}$ These countries figure among the Least Developed Countries (LDCs) according to UN classification (https://www.un.org/development/desa/dpad/least-developed-countrycategory/ldcs-at-a-glance.html), which means that Mozambique and Tanzania are low-income countries with severe structural impediments to sustainable development and low levels of human assets. Both countries entered the oil and gas market few years ago, after the discovery of large, deep-sea, natural gas reserves, without any previous experience in the sector.
} 


\subsection{Analysis of Net LC}

The NLC allows a deeper analysis considering that local first-tier suppliers might import some portions of the inputs used in the production of goods and services they provide to oil and gas companies. In this way, we try to further refine the real quantity of local purchases induced by an oil and gas project. However, as anticipated, the calculation of the NLC requires some assumptions concerning (1) the sectors activated by the project and (2) how local purchases are distributed across those sectors. This makes our results indicative, rather than precise estimates, of how of LC might change when taking into account the level of imports in the purchases of first-tier suppliers.

To identify the main sectors activated by an oil and gas project, we rely on the cost structure of the Rovuma LNG project in terms of sectoral incidences over the total investment, as reported in Table 4.

Table 4 Sectoral composition of Rovuma LNG Project (CAPEX)

\begin{tabular}{lc}
\hline Input supplier sectors & Cost structure ( $\mathbf{q}_{\mathbf{i}} \mathbf{)}$ \\
\hline Metal Products & $34 \%$ \\
Electrical and Machinery & $17 \%$ \\
Transport Equipment & $5 \%$ \\
Construction & $20 \%$ \\
Other Manufacturing & $2 \%$ \\
Financial Intermediation and Business Activities & $22 \%$ \\
\hline
\end{tabular}

Source: Standard Bank Group (2019) study

We first calculate the NLC considering the GLC results from both IOT and ES and distribute the share of local purchases by applying the methodology described in Section 3.3.2 using the portions of local production $\left(\mathrm{y}_{\mathrm{i}}\right)$ reported in Table 5.

Table 5 Portion of local production on the local market by sector

\begin{tabular}{lc}
\hline Input supplier sectors & $\mathbf{y}_{\mathbf{i}}$ \\
\hline Metal Products & $27.0 \%$ \\
Electrical and Machinery & $38.6 \%$ \\
Transport Equipment & $34.8 \%$ \\
Construction & $47.2 \%$ \\
Other Manufacturing & $82.5 \%$ \\
Financial Intermediation and Business Activities & $63.6 \%$ \\
\hline
\end{tabular}

Source: Author's calculations on Eora and Comtrade data.

Table 6 presents the results in terms of NLC obtained assuming the GLC of the project equal to the GLC of the mining and quarrying sector from IOT (78.49\%) and the sectoral GLCi from the same source. Likewise, Table 7 shows the results obtained assuming the GLC of the extraction of crude petroleum and natural gas from ES $(10.00 \%)$ and the sectoral GLCi resulting from its extractive sector supplier sub-sample. The comparison of the results reported in the two tables clearly highlights that IOT data determine an overestimation of NLC (as for the GLC). This overestimation emerges from the computation of the share of domestic purchases for each activated sector (xi): as expected, to obtain a project GLC of $78.49 \%$, every sector should contribute to the total GLC with a higher xi than those required to obtain a GLC around $10 \%$.

Table 6 NLC of a reference project using IOT data

\begin{tabular}{llcccc}
\hline $\mathbf{i}$ & $\begin{array}{l}\text { Input supplier } \\
\text { sectors }\end{array}$ & $\begin{array}{c}\text { Sectoral } \\
\text { structure } \\
\left(\mathbf{q}_{\mathbf{i}}\right) \mathbf{( \% )}\end{array}$ & $\begin{array}{c}\text { Local } \\
\text { purchases } \\
\mathbf{b y ~ s e c t o r} \\
\left(\mathbf{x}_{\mathbf{i}}\right) \mathbf{( \% )}\end{array}$ & $\begin{array}{c}\mathbf{G L C}_{\mathbf{i}} \\
(\mathbf{f r o m} \\
\mathbf{I O T}) \\
\mathbf{\%}\end{array}$ & $\begin{array}{c}\mathbf{N L C}_{\mathbf{i}} \\
\mathbf{\%}\end{array}$ \\
\hline $\mathbf{1}$ & Metal Products & 34.00 & 54.62 & 69.25 & 12.86 \\
$\mathbf{2}$ & Electrical and & 17.00 & 78.06 & 70.58 & 9.37 \\
& Machinery & 5.00 & 70.52 & 73.36 & 2.59 \\
$\mathbf{3}$ & Transport Equipment & 20.00 & 95.63 & 90.79 & 17.36 \\
$\mathbf{4}$ & Construction & 2.00 & $100.00^{*}$ & 75.41 & 1.51 \\
$\mathbf{5}$ & Other Manufacturing & & & 70.94 & \\
$\mathbf{6}$ & Financial & 22.00 & & & 15.61 \\
& $\begin{array}{l}\text { Intermediation and } \\
\text { Business Activities }\end{array}$ & $\mathbf{1 0 0 . 0 0}$ & $100.00^{*}$ & & $\mathbf{5 9 . 2 9}$ \\
\hline
\end{tabular}

Source: Author's calculations on Eora data. * To solve Eq (4) we adopt an iterative algorithm. It means that if we obtain $x_{i}>1$, we impose a share of local purchases of $100 \%$ for the underlying sector and then divide the residual GLC among the other sectors following the same methodology adopted in the first step.

Table 7 NLC of a reference project using ES data

\begin{tabular}{|c|c|c|c|c|c|}
\hline i & $\begin{array}{l}\text { Input supplier } \\
\text { sectors }\end{array}$ & $\begin{array}{c}\text { Sectoral } \\
\text { structure } \\
\left(q_{i}\right)(\%)\end{array}$ & $\begin{array}{c}\text { Local } \\
\text { purchases } \\
\text { by sector } \\
\left(\mathbf{x}_{\mathbf{i}}\right)(\%)\end{array}$ & $\begin{array}{c}\text { GLC }_{\mathbf{i}} \\
\text { (from } \\
\text { ES) } \\
\%\end{array}$ & $\underset{\%}{N_{\%}}$ \\
\hline 1 & Metal Products & 34.00 & 6.34 & 36.86 & 0.79 \\
\hline 2 & $\begin{array}{l}\text { Electrical and } \\
\text { Machinery }\end{array}$ & 17.00 & 9.06 & 43.00 & 0.66 \\
\hline 3 & Transport Equipment & 5.00 & 8.18 & 30.00 & 0.12 \\
\hline 4 & Construction & 20.00 & 11.10 & 70.36 & 1.56 \\
\hline 5 & Other Manufacturing & 2.00 & 19.39 & 66.67 & 0.26 \\
\hline \multirow[t]{4}{*}{6} & Financial & & & & \\
\hline & Intermediation and & 22.00 & & 100.00 & \\
\hline & Business Activities & & 14.95 & & 3.29 \\
\hline & Total & 100.00 & & & 6.69 \\
\hline
\end{tabular}

Table 8 NLC of the Rovuma LNG project (CAPEX) (\%), with IOT and ES data

\begin{tabular}{|c|c|c|c|c|c|c|c|}
\hline \multirow{3}{*}{ i } & \multirow{3}{*}{$\begin{array}{l}\text { Input supplier } \\
\text { sectors }\end{array}$} & \multirow{3}{*}{$\begin{array}{c}\text { CAPEX } \\
\text { (USD } \\
\text { bln) }\end{array}$} & \multirow{3}{*}{$\begin{array}{c}\text { GLC } \\
\text { decompo- } \\
\text { sition } \\
\text { (USD } \\
\text { bln) } \\
\end{array}$} & \multicolumn{4}{|c|}{ NLC } \\
\hline & & & & \multicolumn{2}{|c|}{ IOT } & \multicolumn{2}{|c|}{ ES } \\
\hline & & & & $\begin{array}{c}\text { GLC }_{\mathrm{i}} \\
\%\end{array}$ & $\begin{array}{l}\text { USD } \\
\text { bln }\end{array}$ & $\begin{array}{c}\text { GLC }_{i} \\
\%\end{array}$ & $\begin{array}{l}\text { USD } \\
\text { bln }\end{array}$ \\
\hline 1 & Metal Products & 11.15 & 0.79 & 69.25 & 0.55 & 36.86 & 0.29 \\
\hline 2 & $\begin{array}{l}\text { Electrical and } \\
\text { Machinery }\end{array}$ & 5.58 & - & 70.58 & - & 43.00 & - \\
\hline 3 & $\begin{array}{l}\text { Transport } \\
\text { Equipment }\end{array}$ & 1.64 & - & 73.36 & - & 30.00 & - \\
\hline 4 & Construction & 6.56 & 0.81 & 90.79 & 0.74 & 70.36 & 0.57 \\
\hline 5 & $\begin{array}{l}\text { Other } \\
\text { Manufacturing }\end{array}$ & 0.66 & 0.14 & 75.41 & 0.11 & 66.67 & 0.09 \\
\hline 6 & $\begin{array}{l}\text { Financial } \\
\text { Intermediation } \\
\text { and Business } \\
\text { Activities }\end{array}$ & 7.22 & 1.21 & 70.94 & 0.86 & 100.00 & 1.21 \\
\hline & Total & 32.80 & 2.95 & & 2.25 & & 2.16 \\
\hline & $\%$ over Total & & $9 \%$ & & $6.9 \%$ & & $6.6 \%$ \\
\hline
\end{tabular}

Source: Author's calculations on Rovuma LNG project, IOT and ES data.

Finally, we exploit all the publicly available information about the Rovuma LNG project to estimate its NLC. Specifically, since according to the Standard Bank Group (2019) the largest share of equipment and machinery will be imported, we exclude these sectors from the domestic 
inputs that make up the GLC of the project $(9 \%)$ to solve Eq. (4) using Rovuma LNG project data. Table 8 allows a comparison of the results obtained using the sectoral $\mathrm{GLC}_{\mathrm{i}}$ from both IOT and ES, observing that LC falls from a gross level of $9 \%$ to a NLC in the range between $6.9 \%$ using IOT and $6.6 \%$ with ES data, which means that the NLC of the project is around $3 / 4$ of its GLC. These results provide further evidence of the actual potential of the local supply base when considering the quantity of imports from first-tier suppliers and might be taken as a reference by policy makers for the definition of realistic LC targets well aligned with the development level of the country's industrial supply capacity.

\section{Conclusion}

This paper explores whether and to what extent detailed firm-level data can support the design of LCPs, with special reference to the definition of LC targets of oil and gas projects. In particular, we compare ES data and IOT against the two indicators conventionally used for expressing LC targets, namely GLC and NLC.

The results of our empirical investigations demonstrate how firm-level data collected for Mozambique offer a more accurate understanding of the productive characteristics of the domestic business environment, better supporting the definition of LC targets in the oil and gas sector within a "precision policy" perspective. Specifically, our results show that the GLC in oil and gas extraction is significantly different compared with the other extractive sub-sectors and confirms that in a developing country the extractive sector suppliers have a lower GLC than other firms. As a consequence, IOT data lead to a significant overestimation of GLC. This result is also reflected in the estimate of NLC, which considers the import effects along the supply chain.

These results indicate that firm-level data, like those provided by the ES on Mozambique, can support the policy maker in evaluating more precisely the effects along the supply chain, especially when firm-level data are combined with detailed project data about domestic purchases by sector. In our view, ES data are a powerful instrument to narrow the data gap that affects developing countries and support the design of data-driven policies, constituting an important element to address the poor data-poor policy dilemma. Specifically, our findings suggest that the World Bank special survey for Mozambique, with its focus on extractive sectors, could represent a reference model for data collection to be extended to other resource-rich developing countries to support their LCP definition, starting from those with the lowest statistical capacity.

Finally, it is noteworthy that our exercise takes a snapshot of the LC in Mozambique reflecting its productive structure at a given moment. However, in the mediumterm, the expansion of oil and gas extractive activities could affect the structure of the economy in terms of sectoral composition and production capacity (Nchor and Konderla, 2016). Therefore, LC targets should be regularly updated taking into account the transformation of the local business environment. Accordingly, to support as effectively as possible LCP definition and implementation, firm-wide surveys do not only have to provide specific information on the oil and gas sector and its suppliers but must be repeated over time to monitor the development of the country's production capacity.

\section{References}

Acheampong, T., Ashong, M. and Svanikier, V.C., 2016. An assessment of local-content policies in oil and gas producing countries. The Journal of World Energy Law \& Business, 9(4), pp.282-302.

Adedeji, A.N., Sidique, S.F., Abd Rahman, A. and Law, S.H., 2016. The role of local content policy in local value creation in Nigeria's oil industry: A structural equation modeling (SEM) approach. Resources Policy, 49, pp.61-73.

Adewuyi, A.O. and Oyejide, T.A., 2012. Determinants of backward linkages of oil and gas industry in the Nigerian economy. Resources Policy, 37(4), pp.452-460.

AfDB, OECD and UNDP (2016), Mozambique 2016, in: African Economic Outlook, Paris, online at: www.africaneconomicoutlook.org

Aoun, M.C. and Mathieu, C., 2015. Local content strategies in the oil and gas sector: how to maximise benefits to host communitiesTheme paper For the IFRI/CIEP project for TF3 IGU.

Asali, M., Adbel, G., Walter, M. and Espinasa, R., 2015. Energy Reform and Local Content in Mexico: Effects in the Mining Sector. Inter-American Development Bank, Technical Note No. IDB-TN-771.

Azzone, G., 2018. Big data and public policies: Opportunities and challenges. Statistics \& Probability Letters, 136, pp.116-120.

Balchin, N., 2015. Understanding economic transformation in Africa. Overseas Development Institute, London.

Emmanuel, R., 2016. Optimal local content requirement policies for extractive industries. Resources Policy, 50, pp.244-252.

Furtado, S.R., Júnior, E.D. and Almeida, M.F.L., 2017, October. Evaluation of Social and Economic Impacts of Local Content Management in Oil and gas and Shipbuilding Industry in Brazil: An Application of Input-Output Analysis. In OTC Brasil. Offshore Technology Conference.

Grolinger, K., L'Heureux, A., Capretz, M.A. and Seewald, L., 2016. Energy forecasting for event venues: Big data and prediction accuracy. Energy and Buildings, 112, pp.222-233.

Hansen, M.W., Buur, L., Mette Kjær, A. and Therkildsen, O., 2016, May. The economics and politics of local content in African extractives: lessons from Tanzania, Uganda and Mozambique. In Forum for Development Studies, 43 (2), pp. 201-228. Routledge. 
Heum, P., Kasande, R., Ekern, O.F. and Nyombi, A., 2011. Policy and regulatory framework to enhance local content: yardsticks and best practice.

Hufbauer, G.C., Schott, J.J., Cimino, C., Vieiro, M. and Wada, E., 2013. Local Content Requirements: Report on a Global Problem.

International Petroleum Industry Environmental Conservation Association (IPIECA), 2011. Local content strategy: A guidance document for the oil and gas industry. online: http://www. ipieca. org/publication/local-content-strategy-guidance-document-oiland-gas-industry.

Jerven, M., 2013. Poor numbers: how we are misled by African development statistics and what to do about it. Cornell University Press.

Kazzazi, A. and Nouri, B., 2012. A conceptual model for local content development in petroleum industry. Management Science Letters, 2(6), pp.2165-2174.

Klueh, U.H., Pastor, G. and Segura, A., 2009. Policies to improve the local impact from hydrocarbon extraction: Observations on West Africa and possible lessons for Central Asia. Energy Policy, 37(3), pp.1128-1144.

Kolstad, I. and Kinyondo, A., 2017. Alternatives to local content requirements in resource-rich countries. Oxford Development Studies, 45(4), pp.409-423.

Leontief, W.W., 1936. Quantitative input and output relations in the economic systems of the United States. The review of economic statistics, pp.105-125.

Lenzen M., Moran D., Kanemoto K. and Geschke A. (2013), Building Eora: a Global Multi-Region Input-Output Database at High Country and Sector Resolution, Economic Systems Research, Vol. 25, No. 1, pp.20-49.

Maciejewski, M., 2017. To do more, better, faster and more cheaply: Using big data in public administration. International Review of Administrative Sciences, 83(1_suppl), pp.120-135.

National Resource Governance Institute (NRGI). 2015. Local Content - Strengthening the Local Economy and Workforce.

Nchor, D. and Konderla, T., 2016. Economic multipliers and sectoral linkages: Ghana and the new oil sector. Acta Universitatis Agriculturae et Silviculturae Mendelianae Brunensis, 64(2), pp.635-642.

Nordås, H.K., Vatne, E. and Heum, P., 2003. The upstream petroleum industry and local industrial development: a comparative study.

Nwapi, C., 2015. Defining the "local" in local content requirements in the oil and gas and mining sectors in developing countries. Law and Development Review, 8(1), pp.187-216.

Nwapi C., 2016, A Survey of the Literature on Local Content Policies in the O\&G Industry in East Africa, SPP Research Paper No. 9.

Ovadia, J.S., 2015. The role of local content policies in natural resource-based development. Rohstoffe und Entwicklung, 37.

Ovadia, J.S., 2016. Local content policies and petro-development in Sub-Saharan Africa: A comparative analysis. Resources Policy, 49, pp.20-30.

Pereira, E.G., Mathews, C. and Trischmann, H., 2018. Local Content Policies in the Petroleum Industry: Lessons Learned. ONE J, 4, p.631.

Ramdoo, I., 2015. Unpacking local content requirements in the extractive sector: what implications for the global trade and investment frameworks. International Centre for Trade and Sustainable Development (ICTSD).

Roe, A., 2018. Mozambique-bust before boom: Reflections on investment surges and new gas (No. 2018/140). WIDER Working Paper.

Rui, Z., Cui, K., Wang, X., Chun, J.H., Li, Y., Zhang, Z., Lu, J., Chen, G., Zhou, X. and Patil, S., 2018. A comprehensive investigation on performance of oil and gas development in Nigeria: technical and non-technical analyses. Energy, 158, pp.666-680.

Standard Bank Group (2019), Rovuma LNG Project: Macroeconomic Study, Available on line: https://corporateandinvestment.standardbank.com/static file/CIB/ PDF/2019/Sectors/Oil\%20and\%20Gas/Standard\%20Bank\%20Ro vuma \%20LNG\%20Project\%20English\%20Report.pdf

Teka, Z., 2012. Linkages to manufacturing in the resource sector: the case of the Angolan oil and gas industry. Resources Policy, 37(4), pp.461-467.

Tordo, S. and Anouti, Y., 2013. Local content in the oil and gas sector: Case studies. The World Bank, Washington, DC.

UN, Comtrade dataset, Available online: https://comtrade.un.org/

World Bank Group, 2016. Leveraging a Large Capital Investment to Develop Local Value Chains: Local Content in the Construction of Tanzania's LNG Facility. World Bank.

World Bank, Enterprises Surveys, Available online: https://www.enterprisesurveys.org/en/enterprisesurveys, Date accessed: June 11, 2020

World Bank, Statistical Capacity Indicator Dashboard, Available online:

https://datatopics.worldbank.org/statisticalcapacity/SCIdashboard .aspx, Date accessed: January 31, 2021

White, S., 2017. Regulating for local content: Limitations of legal and regulatory instruments in promoting small scale suppliers in extractive industries in developing economies. The Extractive Industries and Society, 4(2), pp.260-266. 